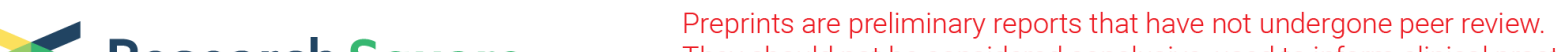 $\begin{array}{ll}\text { Research Square } & \text { They should not be considered conclusive, used to inform clinical practice, } \\ \text { or referenced by the media as validated information. }\end{array}$
}

\section{Direct propylene epoxidation with oxygen enabled by photo-electro-heterogeneous catalytic system}

\section{Myohwa Ko}

Ulsan National Institute of Science and Technology

\section{Yongseon Kim}

Ulsan National Institute of Science and Technology

Jinwoo Woo

Ulsan National Institute of Science and Technology

\section{Rashmi Mehrotra}

Ulsan National Institute of Science and Technology

\section{Pankaj Sharma}

Ulsan National Institute of Science and Technology Jinjong Kim

Ulsan National Institute of Science and Technology

Hu Young Jeong

Ulsan National Institute of Science and Technology

https://orcid.org/0000-0003-2319-260X

\section{Sang Hoon Joo}

Ulsan National Institute of Science and Technology

https://orcid.org/0000-0002-5550-5298

\section{Ji-Wook Jang ( $\sim$ jiwjang@unist.ac.kr)}

Ulsan National Institute of Science and Technology https://orcid.org/0000-0003-1251-1011

\section{Ja Hun Kwak}

Ulsan National Institute of Science and Technology

\section{Article}

Keywords: propylene oxide (PO),plastic

Posted Date: January 13th, 2021

DOI: https://doi.org/10.21203/rs.3.rs-133876/v1

License: (9) This work is licensed under a Creative Commons Attribution 4.0 International License. Read Full License 
Version of Record: A version of this preprint was published at Nature Catalysis on December 30th, 2021. See the published version at https://doi.org/10.1038/s41929-021-00724-9. 


\section{Abstract}

Propylene oxide (PO) is a crucial feedstock in the plastic industry. The direct epoxidation of propylene using $\mathrm{O}_{2}$ is considered to be the most promising means of producing $\mathrm{PO}$, but it remains challenging. Here, we report on an integrated photo-electro-heterogeneous catalytic system for propylene epoxidation with $\mathrm{O}_{2}$. Bismuth vanadate (or $\mathrm{TiO}_{2}$ ) photocatalyst and Co-based electrocatalyst produce $\mathrm{H}_{2} \mathrm{O}_{2}$ and titanium silicalite- 1 heterogeneous catalyst epoxidises propylene to $\mathrm{PO}$ with the in situ generated $\mathrm{H}_{2} \mathrm{O}_{2}$. This system enables $\mathrm{PO}$ production with $\mathrm{O}_{2}$ as the sole oxidising agent under light irradiation without using $\mathrm{H}_{2}$, a sacrificial agent, or external bias. It stably produces $\mathrm{PO}$ for $24 \mathrm{~h}$ with high selectivity $(\geq 98 \%)$ under ambient conditions. These results demonstrate the potential of this new catalytic system to produce chemical compounds in an environmentally benign manner.

\section{Introduction}

Propylene oxide (PO) constitutes one of the most important feedstocks in the plastic industry, which is used to make polyurethane, polyester, and propylene glycol ${ }^{1}$. Its production exceeds 10 million tons per year and demand for PO is gradually increasing ${ }^{2,3}$. Most industrial PO has been produced using either a chlorohydrin or hydroperoxide process ${ }^{4}$. However, they require additional complex purification steps due to the generation of large amounts of coproducts and pose environmental risks due to the use of toxic chemicals and large productions of wastewater. Thus, direct epoxidation using $\mathrm{O}_{2}$, which is a wellestablished method in ethylene oxide production, is considered the most desirable way to produce PO and has been explored intensively ${ }^{5-7}$. However, unlike ethylene, propylene contains allylic hydrogen, and the abstraction of hydrogen can result in further oxidation ${ }^{8}$. Great efforts have been made to develop a process for the direct synthesis of $\mathrm{PO}$ using $\mathrm{O}_{2}$ but such processes have suffered from low activity and selectivity and thus still remain a challenge $e^{9,10}$.

Recently, a propylene epoxidation process using hydrogen peroxide $\left(\mathrm{H}_{2} \mathrm{O}_{2}\right)$ as an oxidising agent (hydrogen peroxide-propylene oxide, HPPO) has received substantial attention because water is the only coproduct and it shows high PO selectivity $(>95 \%)^{11}$. The HPPO process itself is environmentally benign; however, current $\mathrm{H}_{2} \mathrm{O}_{2}$ production through the anthraquinone process involves multi-step reactions and produces large volumes of organic waste ${ }^{12}$. Alternatively, PO production methods using in situ generated $\mathrm{H}_{2} \mathrm{O}_{2}$ have also been developed. For example, Haruta et al. used Au supported on titanium oxides, wherein $\mathrm{H}_{2} \mathrm{O}_{2}$ was synthesised from $\mathrm{H}_{2}$ with $\mathrm{O}_{2}$ on Au and reacted with propylene at nearby isolated $\mathrm{Ti}^{4+}$ sites to produce $\mathrm{PO}^{13}$. Although this process proceeds in a single reaction system, it requires both $\mathrm{O}_{2}$ and $\mathrm{H}_{2}$ to generate $\mathrm{H}_{2} \mathrm{O}_{2}$, which may unavoidably cause safety issues when employed for large-scale production and rapid catalyst deactivation is the most serious problem ${ }^{14,15}$. To date, no approaches have been successful in producing $\mathrm{PO}$ using $\mathrm{O}_{2}$ as the only oxidising agent. 
In this study, we developed an integrated photo-electro-heterogeneous catalytic system by coupling photo-electrochemical $\mathrm{H}_{2} \mathrm{O}_{2}$ production and propylene epoxidation using in situ generated $\mathrm{H}_{2} \mathrm{O}_{2}$ over a titanium silicalite-1 (TS-1). This system is composed of a nanostructured photocatalyst (bismuth vanadate, $\mathrm{BiVO}_{4}$ or $\mathrm{TiO}_{2}$ ), atomically dispersed $\mathrm{Co}-\mathrm{N}_{x}$ electrocatalyst on a carbon nanotube (Co-N/CNT), and heterogeneous catalyst (TS-1). It enables the direct epoxidation of propylene using $\mathrm{O}_{2}$ under light irradiation without any $\mathrm{H}_{2}$, a sacrificial agent, or electrical energy under ambient conditions. This system allows for the stable production of PO over $24 \mathrm{~h}$ with high selectivity $(\geq 98 \%)$ under simulated solar and visible light illumination.

\section{Results}

Photo-electro-heterogeneous catalytic system. To perform propylene epoxidation using $\mathrm{O}_{2}$, the overall reaction should be performed by three catalysts-a photocatalyst for photovoltage generation, an electrocatalyst for selective $\mathrm{O}_{2}$ reduction to $\mathrm{H}_{2} \mathrm{O}_{2}$, and a heterogeneous catalyst for propylene epoxidation with in situ generated $\mathrm{H}_{2} \mathrm{O}_{2}$ (Fig. 1). When a semiconductor photocatalyst receives solar energy, photoexcitation generates charge carriers; the photogenerated hole in the valence band oxidises water to $\mathrm{O}_{2}$ and the electrons move toward the electrocatalyst, which selectively reduces $\mathrm{O}_{2}$ to $\mathrm{H}_{2} \mathrm{O}_{2}$. The heterogeneous catalyst then epoxidises propylene to $\mathrm{PO}$ using in situ $\mathrm{H}_{2} \mathrm{O}_{2}$ as an oxidising agent. In this way, the new catalytic system can produce $\mathrm{PO}$ from propylene, $\mathrm{O}_{2}$, and solar energy without any additional bias or expensive chemicals, making it a straightforward (one-spot), energy-saving $\left(\mathrm{O}_{2}\right.$ as a reactant without a need for electrical energy), and environmentally benign (no toxic chemicals or harmful coproducts) process.

Catalyst characterisation. As a photoanode for oxidising water, a rutile $\mathrm{TiO}_{2}$ nanowire film was employed. The nanowire $\mathrm{TiO}_{2}$ was hydrothermally grown on a fluorine-doped tin oxide (FTO) glass substrate ${ }^{16,17}$. The X-ray diffraction (XRD) pattern of $\mathrm{TiO}_{2}$ showed two diffraction peaks at $36.1^{\circ}$ and $62.8^{\circ}$, which is consistent with that of rutile $\mathrm{TiO}_{2}$ (Fig. 2a). A homogeneous $\mathrm{TiO}_{2}$ film, consisting of vertically aligned, 100-200 nm diameter nanowire arrays, was observed via scanning electron microscopy (SEM) (Fig. 2b). High-resolution transmission electron microscopy (HRTEM) images further revealed that the $\mathrm{TiO}_{2}$ nanowire grew along the [001] direction, with lattice fringes having interplanar spacings of 0.32 and $0.29 \mathrm{~nm}$, consistent with the $d$-spacings of the (110) and (001) planes of rutile $\mathrm{TiO}_{2}$, respectively (Fig. $2 \mathrm{~b}$ inset) ${ }^{18}$.

A Co-N/CNT catalyst was used to selectively reduce $\mathrm{O}_{2}$ to $\mathrm{H}_{2} \mathrm{O}_{2}$. Structural information on the CoN/CNT was gained via extended X-ray absorption fine structure (EXAFS) spectral analyses (Fig. 2c). The radial distribution function from the Fourier-transformed EXAFS spectrum of Co-N/CNT only showed a peak for $\mathrm{Co}-\mathrm{N} / \mathrm{O}$ at $1.45 \AA$, indicating that $\mathrm{Co}-\mathrm{N} / \mathrm{CNT}$ comprises $\mathrm{Co}-\mathrm{N} / \mathrm{O}$ bonds without agglomerated Co particles. The XRD pattern for the Co - N/CNT catalyst showed only broad diffraction peaks near $26^{\circ}$, $43^{\circ}$, and $53^{\circ}$, which originated from the acid-treated CNT support (Supplementary Fig. 1). Furthermore, the 
high-angle annular dark-field scanning TEM (HAADF-STEM) image of Co-N/CNT (Fig. 2d) clearly showed that the atomically dispersed $\mathrm{Co}-\mathrm{N}_{\mathrm{x}}$ sites were homogeneously generated on the CNT.

For propylene epoxidation, a TS-1 catalyst was used. The TS-1 particle ranged in size from $200-300 \mathrm{~nm}$ and exhibited an MFI crystal structure (Fig. 2e, Supplementary Fig. 2). Its Si/Ti molar ratio was 100 and its Brunauer-Emmett-Teller (BET) surface area and pore volume were $488 \mathrm{~m}^{2} \mathrm{~g}^{-1}$ and $0.48 \mathrm{~cm}^{3} \mathrm{~g}^{-1}$, respectively (Supplementary Table 1, Supplementary Fig. 3). Isolated substitution of $\mathrm{Ti}$ in a zeolite framework was confirmed by ultraviolet-visible (UV-Vis) diffuse reflectance and infrared (IR) spectroscopy (Fig. 2f). An absorption band below $250 \mathrm{~nm}$ in the UV-Vis diffuse reflectance spectra was characteristic of isolated framework $\mathrm{Ti}^{4+}$ and there was no extraframework $\mathrm{TiO}_{2}$, as evidenced by the absence of an absorption band near $270-330 \mathrm{~nm}^{11,19}$. A band at $960 \mathrm{~cm}^{-1}$ in the Fourier-transform infrared (FT-IR) spectra was attributed to the stretching of Si-O-Ti bonds in the framework ${ }^{20}$.

\section{Bias-free propylene epoxidation by photo-electro-heterogeneous catalytic system. Photocatalytic} measurements of $\mathrm{TiO}_{2}$ were investigated using a photo-electrochemical cell with a three-electrode configuration. Under sunlight illumination, the photocurrent density of the $\mathrm{TiO}_{2}$ photoanode for water oxidation at $1.23 \mathrm{~V}$ (vs. reversible hydrogen electrode, RHE) was $1.15 \mathrm{~mA} \mathrm{~cm}^{-2}$ with the onset potential of $0.4 \mathrm{~V}$ (vs. RHE) in an Ar-saturated $0.1 \mathrm{M}$ sodium phosphate ( $\mathrm{NaPi}$ ) buffer at pH 6 (Fig. 3a) and showed stable photocurrent for $24 \mathrm{~h}$ (Supplementary Fig. 4a). Because the $\mathrm{TiO}_{2}$ photoanode is stable regardless of the electrolyte's $\mathrm{pH}$, it showed an almost similar photocurrent in a wide range of $\mathrm{pHs}$, allowing for its use at the broad range of $\mathrm{pH}$ electrolytes (Supplementary Fig. 4b).

The electrocatalytic activity and selectivity of the Co-N/CNT catalyst for $\mathrm{H}_{2} \mathrm{O}_{2}$ production were investigated in a $0.1 \mathrm{M} \mathrm{NaPi}$ buffer using a rotating ring disk electrode (RRDE) technique. The oxygen reduction reaction (ORR) polarization curve shows that the Co-N/CNT catalyst began generating the $\mathrm{H}_{2} \mathrm{O}_{2}$ production current from $0.75 \mathrm{~V}$ (vs. $\mathrm{RHE}$ ) in the $\mathrm{O}_{2}$-saturated $0.1 \mathrm{M} \mathrm{NaPi}$ buffer at pH 6 (Fig. 3b). Rotating ring disk electrode and Koutecky-Levich analyses indicated the consistently high $\mathrm{H}_{2} \mathrm{O}_{2}$ selectivity (70-80\%) of the Co-N/CNT catalyst (Fig. 3b, Supplementary Fig. 5). The Co-N/CNT catalyst was also active for electrochemical $\mathrm{H}_{2} \mathrm{O}_{2}$ production under various $\mathrm{pH}$ conditions $(\mathrm{pH} 2-8)$, extending the potential applicability of this catalyst for use with other photoanodes (Supplementary Fig. 6). In particular, even in an acidic electrolyte, where the dissolution of metal species or the oxidation of carbon surfaces is prominent ${ }^{21}$, the Co - N/CNT catalyst exhibited a constant current and high selectivity for $\mathrm{H}_{2} \mathrm{O}_{2}$ production. We assessed the long-term durability of the $\mathrm{Co}-\mathrm{N} / \mathrm{CNT}$ catalyst by potential cycling in the range of $0.6-1.0 \mathrm{~V}$ and at a scan rate of $50 \mathrm{mV} \mathrm{s}^{-1}$ in an $\mathrm{O}_{2}$-saturated $0.1 \mathrm{M} \mathrm{NaPi}$ buffer solution. After the durability test, high peroxide current density and selectivity for $\mathrm{H}_{2} \mathrm{O}_{2}$ production were maintained, demonstrating the catalyst's excellent stability (Supplementary Fig. 7). Furthermore, brightfield STEM (BF-STEM) and HAADF-STEM images of Co-N/CNT before and after the durability test were nearly the same, indicating that atomically dispersed Co species were not agglomerated or detached from CNT support (Supplementary Fig. 8). 
Next, a $\mathrm{TiO}_{2}$ photoanode and a piece of carbon paper coated with a Co-N/CNT catalyst as a cathode were prepared for the photo-electrochemical $\mathrm{H}_{2} \mathrm{O}_{2}$ production. Bias-free photo-electrochemical $\mathrm{H}_{2} \mathrm{O}_{2}$ production occurs when an intersection exists in the linear sweep voltammetry (LSV) curves of a photoanode and cathode. The predicted operating current of the integrated photo-electrochemical cell was $1.36 \mathrm{~mA}$ at $0.51 \mathrm{~V}$ (vs. RHE) as shown in Fig. 3c. Actual bias-free photo-electrochemical $\mathrm{H}_{2} \mathrm{O}_{2}$ production was performed by connecting $\mathrm{TiO}_{2}$ photoanode and $\mathrm{Co}-\mathrm{N} / \mathrm{CNT}$ cathode using alligator clips and copper wire as an external circuit in $\mathrm{Ar}$ - and $\mathrm{O}_{2}$-saturated $0.1 \mathrm{M} \mathrm{NaPi}$ buffers, respectively. To verify the photo-electrochemical $\mathrm{H}_{2} \mathrm{O}_{2}$ production, the amount of $\mathrm{H}_{2} \mathrm{O}_{2}$ was estimated as a function of time using a colorimetric method with N,N-diethyl-p-phenylenediamine (DPD) ${ }^{22,23}$. We observed the continuous production of $\mathrm{H}_{2} \mathrm{O}_{2}$ over $5 \mathrm{~h}$ of reaction, confirming that it can continuously supply $\mathrm{H}_{2} \mathrm{O}_{2}$ for propylene epoxidation by TS-1 (Fig. 3d).

Propylene epoxidation was performed using photo-electrochemically produced $\mathrm{H}_{2} \mathrm{O}_{2}$ in a $0.1 \mathrm{M} \mathrm{NaPi}$ buffer at $\mathrm{pH} 6$, in which TS-1 was dispersed in a cathodic electrolyte with the supply of propylene and $\mathrm{O}_{2}$. As shown in Fig. $3 e, \mathrm{PO}$ was simultaneously produced with $\mathrm{H}_{2} \mathrm{O}_{2}$ generation and its production increased linearly with time. The remaining $\mathrm{H}_{2} \mathrm{O}_{2}$ was nearly constant after $1 \mathrm{~h}$, which indicates that the generated $\mathrm{H}_{2} \mathrm{O}_{2}$ was promptly consumed by propylene epoxidation. The sum of the PO production and remaining $\mathrm{H}_{2} \mathrm{O}_{2}$ was well-matched to the amount of $\mathrm{H}_{2} \mathrm{O}_{2}$ production in the absence of TS-1, indicating nearly $100 \%$ of $\mathrm{H}_{2} \mathrm{O}_{2}$ utilisation (Fig. 3d, e).

The catalytic system exhibited steady PO production for $24 \mathrm{~h}$ (total $205 \mu \mathrm{mol}$, Fig. 3e inset). It is notable that $\mathrm{O}_{2}$ was the only oxidising agent in the overall reaction $\left(\mathrm{C}_{3} \mathrm{H}_{6}+0.5 \mathrm{O}_{2} \rightarrow \mathrm{C}_{3} \mathrm{H}_{6} \mathrm{O}\right)$. Propylene epoxidation was performed at various $\mathrm{pH}$ values and the production rate of $\mathrm{PO}$ was found to be the highest at pH $6\left(10.9 \mu \mathrm{mol} \mathrm{h}^{-1}\right)$ with $100 \%$ PO selectivity (Fig. 3f, Supplementary Fig. 9). As the pH decreased from $\mathrm{pH}$ 6, the production rates of both $\mathrm{H}_{2} \mathrm{O}_{2}$ and $\mathrm{PO}$ declined (Supplementary Fig. 10, Fig. 3f). In an acidic buffer, propylene glycol (PG) was formed due to the hydrolysis of PO (Fig. 3f, Supplementary Fig. 9b), resulting in low PO selectivity $(\sim 40 \% \text { PO selectivity at } \mathrm{pH} 2)^{24}$. At $\mathrm{pH}$ values of 7 and $8, \mathrm{PO}$ selectivity was $100 \%$, but PO production decreased, which may be attributable to the inhibition of propylene epoxidation on TS-1 by alkali metals in the buffer solutions (Fig. $3 f)^{25}$. In this catalytic system, most $\mathrm{PO}$ was detected in the gaseous phase due to its high vapour pressure and continuous purging by $\mathrm{O}_{2}$ and propylene; less than $5 \%$ of all PO remained in the liquid phase based on the total PO production after $5 \mathrm{~h}$. At low $\mathrm{pH}$ values, $\mathrm{PG}$ was detected in the liquid phase because of its low vapour pressure. There were no other detectable byproducts. In the absence of the TS-1 catalyst, PO and byproducts were not produced, demonstrating that the TS- 1 catalyst was essential for propylene epoxidation (Supplementary Fig. 11).

Bias-free propylene epoxidation under visible light illumination. We employed a $\mathrm{TiO}_{2}$ semiconductor as a photoanode to observe the effects of $\mathrm{pH}$ on propylene epoxidation via photo-electro-heterogeneous catalytic system because $\mathrm{TiO}_{2}$ photoanodes are stable across a wide range of electrolyte $\mathrm{pH}$ values. 
However, a $\mathrm{TiO}_{2}$ photoanode can only utilise UV light, which is $<5 \%$ of the full sunlight spectrum, because of its large bandgap. This limits the effective use of sunlight to drive water oxidation. In contrast, $\mathrm{BiVO}_{4}$ photoanode can utilise the visible light region, owing to its suitable bandgap of $\sim 2.4 \mathrm{eV}^{26}$. Hence, we applied a cobalt phosphate (CoPi)-modified $\mathrm{BiVO}_{4}$ film as a second photoanode to produce $\mathrm{PO}$ under visible light. The nanoporous $\mathrm{BiVO}_{4}$ film on the FTO substrate was prepared according to methods reported in the literature ${ }^{27}$ and then a CoPi cocatalyst was photo-electrochemically deposited on the $\mathrm{BiVO}_{4}$ film to promote the kinetics of water oxidation and improve photoanode stability ${ }^{28}$. The XRD pattern of bare $\mathrm{BiVO}_{4}$ can be well assigned to monoclinic $\mathrm{BiVO}_{4}$ (Supplementary Fig. 12a), while the SEM image of the nanoporous $\mathrm{CoPi} / \mathrm{BiVO}_{4}$ electrode showed a particle size of $150-250 \mathrm{~nm}$ in diameter and a uniform thickness of $1.2 \mu \mathrm{m}$ (Supplementary Fig. 13). The optical bandgap for nanoporous $\mathrm{CoPi} / \mathrm{BiVO}_{4}$ was estimated to be $\sim 2.6 \mathrm{eV}$ using a Tauc plot (Supplementary Fig. 12b). The LSV curve of the resulting $\mathrm{CoPi} / \mathrm{BiVO}_{4}$ photoanode for water oxidation under visible light $(\lambda>420 \mathrm{~nm})$ was obtained by showing a $1.73 \mathrm{~mA} \mathrm{~cm}^{-2}$ photocurrent density at $1.23 \mathrm{~V}$ (vs. RHE), while a negligible $\mathrm{TiO}_{2}$ photoanode photocurrent was observed (Fig. 4a). For comparison, the $\mathrm{CoPi} / \mathrm{BiVO}_{4}$ and $\mathrm{TiO}_{2}$ photoanode $\mathrm{LSV}$ curves under simulated solar light irradiation are shown in Supplementary Fig. 14. The nanoporous $\mathrm{CoPi} / \mathrm{BiVO}_{4}$ exhibited a higher photocurrent density when compared to $\mathrm{TiO}_{2}$ photoanode of the same size, though we utilised a large active area of the CoPi/BiVO ${ }_{4}$ film (active area: $3.4 \mathrm{~cm}^{2}$ ), which typically shows higher photocurrent densities over small active areas $\left(<0.5 \mathrm{~cm}^{2}\right)^{29,30}$. The LSV curve of the bare $\mathrm{BiVO}_{4}$ photoanode is also shown. After the photo-electrodeposition of $\mathrm{CoPi}$ on $\mathrm{BiVO}_{4}$, the current density of the $\mathrm{CoPi} / \mathrm{BiVO}_{4}$ photoanode increased to $1.73 \mathrm{~mA} \mathrm{~cm}^{-2}$ at $1.23 \mathrm{~V}$ (vs. RHE), as compared to that of bare $\mathrm{BiVO}_{4}\left(0.96 \mathrm{~mA} \mathrm{~cm}{ }^{-2}\right.$ at $1.23 \mathrm{~V}$ (vs. RHE)), with a significant potential shift in cathodic onset (Fig. 4a).

When the nanoporous $\mathrm{CoPi} / \mathrm{BiVO}_{4}$ photoanode was integrated with the Co-N/CNT cathode for the photoelectrochemical $\mathrm{H}_{2} \mathrm{O}_{2}$ production under visible light $(\lambda>420 \mathrm{~nm})$, the intersection point was $1.46 \mathrm{~mA}$ at $0.48 \mathrm{~V}$ (vs. RHE) (Fig. 4b). It generated a total of $74.2 \mu \mathrm{mol}$ of $\mathrm{H}_{2} \mathrm{O}_{2}$ over 5 hours in a $0.1 \mathrm{M} \mathrm{NaPi}$ buffer at a pH 6, while no $\mathrm{H}_{2} \mathrm{O}_{2}$ production was observed when the $\mathrm{TiO}_{2}$ photoanode was used due to its large bandgap (Fig. 4c). Additionally, an $\mathrm{H}_{2} \mathrm{O}_{2}$ production experiment was also performed using a powder-type $\mathrm{BiVO}_{4}$ photocatalyst to compare the photo-electrochemical and powder-type photocatalytic systems. The powder-type $\mathrm{BiVO}_{4}$ photocatalyst could not produce $\mathrm{H}_{2} \mathrm{O}_{2}$ in the absence of a sacrificial agent, suggesting that the integrated photo-electrochemical system is essential for bias-free $\mathrm{H}_{2} \mathrm{O}_{2}$ production (Fig. 4c).

We next performed propylene epoxidation over TS-1 using photo-electrochemically produced $\mathrm{H}_{2} \mathrm{O}_{2}$ from a $\mathrm{CoPi} / \mathrm{BiVO}_{4}$ photoanode and Co-N/CNT cathode under visible light $(\lambda>420 \mathrm{~nm})$. The stable and continuous production of $\mathrm{PO}$ was observed for $5 \mathrm{~h}$ of reaction, with a production rate of $12 \mu \mathrm{mol} \mathrm{h} \mathrm{h}^{-1}$ (Fig. 4d). Moreover, the amount of $\mathrm{H}_{2} \mathrm{O}_{2}$ production in the absence of TS-1 based on the sum of the PO production and remaining $\mathrm{H}_{2} \mathrm{O}_{2}$, indicated almost $100 \%$ of $\mathrm{H}_{2} \mathrm{O}_{2}$ utilisation (Supplementary Fig. 15) and it 
showed steady production for $24 \mathrm{~h}$, yielding a total of $224 \mu \mathrm{mol}$ of PO (Fig. $4 \mathrm{~d}$ inset). These results indicate that our photo-electro-heterogeneous catalytic system could also stably produce PO under visible light irradiation, suggesting that it has potential applications in commercial light-emitting diode bulbs and under ambient sunlight. In contrast, $\mathrm{PO}$ was not produced when the $\mathrm{TiO}_{2}$ photoanode and $\mathrm{BiVO}_{4}$ powder were used because they could not produce $\mathrm{H}_{2} \mathrm{O}_{2}$ under visible light without the help of a sacrificial agent (Fig. 4d). Finally, when the $\mathrm{BiVO}_{4}$ photoanode was applied to the system under simulated solar light irradiation, it showed a higher $\mathrm{PO}$ production than that of $\mathrm{TiO}_{2}$ photoanode (Supplementary Fig. 16, Supplementary Table 2).

\section{Conclusions}

The results of this study demonstrate that the newly developed photo-electro-heterogeneous catalytic system can successfully produce $\mathrm{PO}$ from propylene and $\mathrm{O}_{2}$. With $\mathrm{TiO}_{2}$ photoanode, it showed the highest PO production rate $\left(10.9 \mu \mathrm{mol} \mathrm{h}^{-1}\right.$ for $\left.5 \mathrm{~h}\right)$ and $100 \% \mathrm{PO}$ selectivity at $\mathrm{pH} 6$ under simulated solar light. This system stably produced $204 \mu \mathrm{mol}$ of PO with high selectivity (98\%) for $24 \mathrm{~h}$. Moreover, it could also operate under visible light illumination with $\mathrm{CoPi} / \mathrm{BiVO}_{4}$ photoanode showing stable and continuous PO production up to $224 \mu \mathrm{mol}$ for $24 \mathrm{~h}$. This integrated system has great advantages in that it uses $\mathrm{O}_{2}$ instead of expensive reagents (e.g., $\mathrm{H}_{2}$ or $\mathrm{H}_{2} \mathrm{O}_{2}$ ) and its overall reactions take place in a single, environmentally friendly system without the use of any additional bias or sacrificial agents. We believe that this system provides an unprecedented way of producing $\mathrm{PO}$ with $\mathrm{O}_{2}$ beyond the currently available methods of PO production and should broaden the applicability of photocatalysis in the chemical industry.

\section{Methods}

Photocatalyst synthesis. A rutile $\mathrm{TiO}_{2}$ nanowire film was hydrothermally grown on a FTO substrate ${ }^{16,17}$. First, $15 \mathrm{~mL}$ of hydrochloric acid (35\%, Samchun Chemical Co., Ltd., Republic of Korea) was diluted with $15 \mathrm{~mL}$ of deionised (DI) water and mixed with $0.5 \mathrm{~mL}$ of titanium (IV) butoxide (97\%, MilliporeSigma, USA). This clear solution was transferred to a Teflon-lined stainless-steel autoclave $(125 \mathrm{~mL})$ and the FTO substrate was submerged in the solution. The sealed autoclave was kept in an oven at $150^{\circ} \mathrm{C}$ for $5 \mathrm{~h}$ and then cooled to room temperature (RT) slowly. After rinsing and drying, the sample was annealed at $550^{\circ} \mathrm{C}$ for $5 \mathrm{~h}$ to increase crystallinity.

A nanoporous $\mathrm{BiVO}_{4}$ film was prepared according to previously reported methods ${ }^{27}$. Briefly, three solutions for synthesising $\mathrm{BiVO}_{4}$ were prepared. First, a bismuth nitrate solution was prepared by dissolving $0.04 \mathrm{M}$ of bismuth nitrate pentahydrate ( $\geq 99.99 \%$, MilliporeSigma, USA) in $0.4 \mathrm{M}(50 \mathrm{~mL})$ of a potassium iodide solution ( $99 \%$, FujiFilm Wako Chemicals USA Corp., USA). The pH of this solution was then reduced to 1.7 by adding $\mathrm{HNO}_{3}(60 \%$, Junsei Chemical Co., Ltd., Japan). The second solution consisted of $0.23 \mathrm{M}$ of p-benzoquinone ( $\geq 98 \%$, MilliporeSigma, USA) in absolute ethanol $(20 \mathrm{~mL})$. Later, 
both solutions were mixed to obtain a dark brown BiOl precursor solution. A dark orange BiOl layer was electrodeposited on the FTO by applying a constant potential of $-0.1 \mathrm{~V}$ against $\mathrm{Ag} / \mathrm{AgCl}(\mathrm{RE}-1 \mathrm{~B}, \mathrm{ALS})$ for 420 s. Next, $0.4 \mathrm{M}$ of vanadyl acetylacetonate ( $98 \%$, MilliporeSigma, USA) in dimethyl sulfoxide ( $99 \%$, Kanto Chemical Co., Inc., Japan) was prepared for converting the $\mathrm{BiOl}$ to $\mathrm{BiVO}_{4}$. This solution was uniformly drop-cast on the BiOl layer and then the film was annealed at $450^{\circ} \mathrm{C}$ for $2 \mathrm{~h}$. Finally, a brownish crust was removed from the samples by washing with $1 \mathrm{M}$ of $\mathrm{NaOH}(98 \%$, Alfa Aesar, USA) for 30 min and $\mathrm{CoPi}$ was applied onto the $\mathrm{BiVO}_{4}$ photoanode via photo-assisted electrodeposition ${ }^{28}$. A threeelectrode cell was used with the $\mathrm{BiVO}_{4}$ working electrode (one sun position), $\mathrm{Ag} / \mathrm{AgCl}$ reference electrode, and a Pt mesh counter electrode and CoPi was deposited for $6 \mathrm{~min}$ at $\sim 0.2-0.3 \mathrm{~V}$ (vs. RHE) with photocurrent densities of $\sim 1-4 \mu \mathrm{A} \mathrm{cm}^{-2}$ in a $0.1 \mathrm{M}$ potassium phosphate buffer at $\mathrm{pH} 6.7$ and containing $0.5 \mathrm{mM}$ of cobalt nitrate ( $98 \%$, Alfa Aesar, USA).

An $\mathrm{m}^{-\mathrm{BiVO}_{4}}$ powder was synthesised under ambient conditions using a novel solid-liquid reaction ${ }^{31}$, in which equimolar concentrations of bismuth (III) oxide ( $99.9 \%$, MilliporeSigma, USA) and vanadium oxide ( $\geq 99.6 \%$, MilliporeSigma, USA) were dissolved in $250 \mathrm{~mL}$ of $0.5 \mathrm{M} \mathrm{HNO}_{3}$ with high-speed stirring. Yellow m-BiVO ${ }_{4}$ particles were collected via suction filtration after four days of mixing, followed by repeated washings with DI water to remove the unreacted dissolved species and $\mathrm{HNO}_{3}$ before drying at $110^{\circ} \mathrm{C}$.

Photoanode characterisation. The XRD patterns of photoanode films were recorded using an X'Pert PRO diffractometer (Malvern Pananalytical, UK) with Cu Ka radiation $(\lambda=1.5406 \AA)$ from $10-70^{\circ}$ in $2 \theta$ at a scanning speed of $1^{\circ} \mathrm{min}^{-1}$. The HRTEM and SEM images were obtained using a JEM-2100F (JEOL, Ltd., Japan) microscope and a SU8220 (Hitachi High-Technologies Corp., Japan), respectively. Optical properties were determined by UV-vis diffuse reflectance spectroscopy using a UV-3600 (Shimadzu Corp., Japan).

Electrocatalyst synthesis. Synthesis of Co-N/CNT, employing CoTMPP as the Co and N precursors, was conducted following a silica coating-mediated process with some modifications ${ }^{23}$. We ground $0.28 \mathrm{~g}$ of CoTMPP in a mortar for $5 \mathrm{~min}$ and the resulting fine powder was mixed with $0.2 \mathrm{~g}$ of acid-treated CNT for $10 \mathrm{~min}$. The CoTMPPCl-CNT mixture was heated to $400^{\circ} \mathrm{C}$ at a ramping rate of $2^{\circ} \mathrm{C} \mathrm{min}^{-1}$ and maintained at $400^{\circ} \mathrm{C}$ for $3 \mathrm{~h}$ under $\mathrm{N}_{2}$ gas (99.999\%) and a flow rate of $1 \mathrm{~L} \mathrm{~min}{ }^{-1}$. The resulting composite was mixed with $1.0 \mathrm{~mL}$ of TEOS in a mortar, followed by mixing with $1.0 \mathrm{~mL}$ of formic acid. The paste-like mixture was kept at RT for $12 \mathrm{~h}$ in a fume hood, then heated to $900^{\circ} \mathrm{C}$ at a ramping rate of $2^{\circ} \mathrm{C} \min ^{-1}$, and maintained at that temperature for $3 \mathrm{~h}$. To etch the silica, the pyrolyzed composite was mixed with 1:1 (v/v) of ethanol-10\% aqueous HF solution. The slurry was stirred for $30 \mathrm{~min}$, filtered, and washed with ethanol several times. Finally, the HF etching process was repeated in the same manner and the product was oven-dried at $60^{\circ} \mathrm{C}$.

Electrochemical characterisation (RRDE). Electrochemical measurements were conducted using an electrochemical workstation (CHI760E, CH Instruments, Inc., USA). The three-electrode system was constructed for measurement using a graphite rod counter electrode, an $\mathrm{Ag} / \mathrm{AgCl}$ reference electrode, and 
a catalyst-loaded RRDE, AFE7R9GCPT, Pine Research Instrumentation, Inc., USA). Before each use, the RRDE was polished with 1.0 and $0.3 \mu \mathrm{m}$ of aqueous alumina suspensions and a microcloth. The Co$\mathrm{N} / \mathrm{CNT}$ catalyst ink was prepared by mixing $5 \mathrm{mg}$ of catalyst, $50 \mu \mathrm{L}$ of DI water, $12.5 \mu \mathrm{L}$ of Nafion dispersion (5 wt.\%, D521, Dupont de Nemours, Inc., USA), and $537 \mu \mathrm{L}$ of anhydrous ethanol. The catalyst ink was homogenised using an ultrasonic bath. Then, $6 \mu \mathrm{L}$ of the ink was deposited onto the RRDE disk. The resulting catalyst loading was $0.2 \mathrm{mg} \mathrm{cm}^{-2}$. After soaking the catalyst-loaded RRDE into a $\mathrm{N}_{2}^{-}$ saturated electrolyte, cyclic voltammetry (CV) was performed between 0.05 and $1.20 \mathrm{~V}$ (vs. RHE) at a scan rate of $100 \mathrm{mV} \mathrm{s}^{-1}$. Steady CV responses were observed within 20 cycles. The Pt ring of the RRDE was electrochemically cleaned in the same potential range with a scan rate of $500 \mathrm{mV} \mathrm{s}^{-1}$ for 50 cycles. Electrochemical impedance spectroscopy was performed at $0.68 \mathrm{~V}$ (vs. RHE) from 100,000-1 Hz at an electrode rotation speed of $1600 \mathrm{rpm}$ in an $\mathrm{O}_{2}$-saturated electrolyte. The series resistance was determined at the high-frequency tail of the Nyquist plot for iR-compensation. The ORR polarization curve was obtained by LSV from 1.2-0.2 V (vs. RHE) at a scan rate of $5 \mathrm{mV} \mathrm{s}^{-1}$ and at electrode rotation speeds of 2025, 1600, 1225, and 900 rpm for Koutecky-Levich analysis (Equation (1)). To correct the non-Faradaic current (capacitive current) from the LSV curve, the same measurements were made in an $\mathrm{N}_{2}$-saturated electrolyte.

$$
\frac{1}{i}=\frac{1}{i_{\mathrm{k}}}+\frac{1}{0.62 n F A D_{0}^{2 / 8} v^{-1 / 6} C_{0} \omega^{1 / 2}}=\frac{1}{i_{\mathrm{k}}}+\frac{1}{B \times \omega^{1 / 2}}
$$

In equation (1), $i, i_{k}, n, F, A, D_{0}, v, C_{0}$, and $\omega$ represent the measured current, kinetic current, electron transfer number, Faraday constant $\left(96,485 \mathrm{C} \mathrm{mol}^{-1}\right)$, diffusion coefficient of $\mathrm{O}_{2}$, kinematic viscosity, $\mathrm{O}_{2}$ concentration, and the electrode rotation speed, respectively. The plot of $\Gamma^{-1}$ as a function of $\omega^{-1 / 2}$ yields a line with a slope of $B^{-1}$, which was used to calculate $n$. The $D_{0}, v$, and $C_{0}$ values vary with the electrolyte chosen; here, $D_{0}=8.90 \times 10^{-6} \mathrm{~cm}^{2} \mathrm{~s}^{-1}, v=0.0111 \mathrm{~cm}^{2} \mathrm{~s}^{-1}$, and $C_{0}=1.21 \times 10^{-6} \mathrm{~mol} \mathrm{~cm}^{-3}$ for a $0.1 \mathrm{M}$ $\mathrm{NaPi}$ electrolyte $32-34$.

To measure $\mathrm{H}_{2} \mathrm{O}_{2}$ yield, the Pt ring potential was held at $1.3 \mathrm{~V}$ (vs. RHE) during the LSV measurements and the $\mathrm{H}_{2} \mathrm{O}_{2}$ selectivity was then calculated according to the following equation:

$$
\mathrm{H}_{2} \mathrm{O}_{2} \text { selectivity }(\%)=\frac{200}{1+\frac{N \times i_{\mathrm{d}}}{i_{\mathrm{r}}}},
$$

where $i_{d}, i_{r}$, and $N$ indicate the disk current, ring current, and the collection efficiency (37\%, provided by the manufacturer), respectively. To assess the durability of the catalysts, potential cycling tests were performed between 0.6 and $1.0 \mathrm{~V}$ (vs. RHE) with an electrode rotation of $1600 \mathrm{rpm}$ and a scan rate of 50 $\mathrm{mV} \mathrm{s}^{-1}$ for 1000 cycles in the $\mathrm{O}_{2}$-saturated electrolyte. After cycling, the ORR activity was measured in a fresh electrolyte. 
Photo-electrochemical measurements of photoanode and cathode. The LSV curves of the photoanodes were measured using a digital multimeter (Ivium-n-Stat Multichannel potentiostat, Ivium Technologies, The Netherlands) with an $\mathrm{Ag} / \mathrm{AgCl}$ reference electrode and a Pt wire counter electrode in an Ar-saturated $0.1 \mathrm{M} \mathrm{NaPi}$ solution from $0-2 \mathrm{~V}$ (vs. RHE) and at a scan rate of $10 \mathrm{mV} \mathrm{s}^{-1}$. The photoanode $\left(3.4 \mathrm{~cm}^{2}\right)$ was illuminated using a $300 \mathrm{~W}$ Xe arc lamp (66902 Newport Corp., USA) with an AM $1.5 \mathrm{G}$ filter at 100 $\mathrm{mW} \mathrm{cm}{ }^{-2}$ under one sun of simulated illumination. For visible light illumination, the intensity was adjusted to $160 \mathrm{~mW} \mathrm{~cm}^{-2}$ with a $420 \mathrm{~nm}$ cutoff filter. The light intensity was adjusted using a standard Si cell (PEC-SI01, Peccell Technologies, Inc., Japan). The LSV curves of the Co-N/CNT cathode (geometric area $=3.74 \mathrm{~cm}^{2}$ ) were also measured from $1.2-0.05 \mathrm{~V}\left(\mathrm{vs}\right.$. RHE) at a scan rate of $5 \mathrm{mV} \mathrm{s}^{-1}$ in an $\mathrm{O}_{2^{-}}$ saturated $0.1 \mathrm{M} \mathrm{NaPi}$ solution at $\mathrm{pH} 6$.

TS-1 synthesis. We synthesised TS-1 as previously reported in the literature ${ }^{35} ; 2 \mathrm{~g}$ of Tween 20 (MilliporeSigma, USA) was added to $21 \mathrm{ml}$ of DI water and this solution was added to $30.3 \mathrm{~g}$ of a tetrapropylammonium hydroxide solution (1 $\mathrm{M}$ in water, MilliporeSigma, USA) dropwise under stirring. To this mixed solution, $36 \mathrm{~g}$ of tetraethyl orthosilicate ( $\geq 99.0 \%$, MilliporeSigma, USA) was added dropwise under stirring. After $1 \mathrm{~h}$ of stirring, $0.61 \mathrm{~g}$ of titanium (IV) butoxide (97\%, MilliporeSigma, USA) in $9.12 \mathrm{~g}$ of isopropyl alcohol (IPA, $\geq 99.5 \%$, Daejung Chemicals and Metals Co., Ltd., Republic of Korea) was added dropwise. The molar ratio of the synthesis gel was $1 \mathrm{SiO}_{2}: 0.01 \mathrm{TiO}_{2}: 0.17 \mathrm{TPAOH}: 14.5 \mathrm{H}_{2} \mathrm{O}: 0.009$ Tween20:0.88 IPA. After stirring for another $1 \mathrm{~h}$, the resulting solution was transferred into a Teflon-lined stainless autoclave and heated at $150^{\circ} \mathrm{C}$ for $20 \mathrm{~h}$. The precipitates were separated by centrifugation, washed with water several times, and dried at $110^{\circ} \mathrm{C}$ overnight. The synthesised sample was calcined in a muffle furnace at $550^{\circ} \mathrm{C}$ for $15 \mathrm{~h}$.

TS-1 characterisation. The XRD pattern of TS-1 was collected on a D2 phaser (Bruker Corp., USA) using Cu Ka radiation from $5-50^{\circ}$ in $2 \theta$ at a scanning speed of $0.1^{\circ} \mathrm{s}^{-1}$. The $\mathrm{N}_{2}$ sorption isotherm was performed using Belsorp-Max II (MicrotracBEL, Japan). Scanning electron microscopy was performed using an SU-8220 (Hitachi High-Technologies Corp., Japan) at $5 \mathrm{kV}$. Ultraviolet-visible diffuse reflectance and infrared spectra were recorded on a Cary 5000 (Agilent Technologies, Inc., USA) and Nicolet iS 50 FTIR spectrometer (Thermo Fisher Scientific, USA), respectively.

Hydrogen peroxide detection. The amount of $\mathrm{H}_{2} \mathrm{O}_{2}$ was estimated using the DPD method ${ }^{22}$. First, DPD and peroxidase (POD) solutions were prepared by dissolving $0.05 \mathrm{~g}$ of DPD ( $\geq 98.0 \%$, MilliporeSigma, USA) in $5 \mathrm{~mL}$ of $0.1 \mathrm{~N} \mathrm{H}_{2} \mathrm{SO}_{4}$ and $5 \mathrm{mg}$ of POD (horseradish, MilliporeSigma, USA) in $5 \mathrm{~mL}$ of DI water, respectively. These solutions were kept at $5^{\circ} \mathrm{C}$. Next, $2.7 \mathrm{~mL}$ of a $0.1 \mathrm{M} \mathrm{NaPi}$ buffer $(\mathrm{pH} 6.0), 0.05 \mathrm{~mL}$ of DPD solution, $0.05 \mathrm{~mL}$ of POD solution, and $0.2 \mathrm{~mL}$ of sample were mixed. The absorbance of the mixed solution at $\lambda=551 \mathrm{~nm}$ was measured using a UV-2600 (Shimadzu Corp., Japan). The amount of $\mathrm{H}_{2} \mathrm{O}_{2}$ was calculated from an external standard curve $\left(R^{2}>0.99\right)$.

Propylene epoxidation in photo-electro-heterogeneous catalytic system and product analysis. The overall reaction was performed in a single reactor composed of an anode cell and a cathode cell. The anode cell 
was separated from the cathode cell through a $0.18 \mathrm{~mm}$-thick Nafion membrane (Nafion ${ }^{\circledR} 117$, MilliporeSigma, USA) and a $0.1 \mathrm{M} \mathrm{NaPi}$ solution $(\mathrm{pH} 2-8)$ was used as the electrolyte. The anode and cathode cells consisted of a photoanode $\left(3.4 \mathrm{~cm}^{2}\right)$ with $28 \mathrm{~mL}$ electrolyte and Co-N/CNT cathode (geometric area $=3.74 \mathrm{~cm}^{2}$ ) with TS-1 $\left(5 \mathrm{mg} \mathrm{mL}^{-1}\right)$ in a $9 \mathrm{~mL}$ electrolyte, respectively. The photoanode and cathode were connected with alligator clips and copper wire as an external circuit.

In the photocatalytic powder system, $\mathrm{BiVO}_{4}$ powder $\left(2.5 \mathrm{mg} \mathrm{mL}^{-1}\right)$ and TS-1 $\left(5 \mathrm{mg} \mathrm{mL}^{-1}\right)$ were added together in a $9 \mathrm{~mL}$ electrolyte in a single cell. The photoanode (or $\mathrm{BiVO}_{4}$ powder) was illuminated using a 300 W Xe arc lamp (66902 Newport Corp., USA) with an AM $1.5 \mathrm{G}$ filter at $100 \mathrm{~mW} \mathrm{~cm}^{-2}$ under one sun of illumination. For visible light illumination, the intensity was adjusted to $160 \mathrm{~mW} \mathrm{~cm}^{-2}$ with a $420 \mathrm{~nm}$ cutoff filter. Argon gas was continuously bubbled into the anode electrolyte and $\mathrm{O}_{2}$ and $\mathrm{C}_{3} \mathrm{H}_{6}$ gas were continuously bubbled into the cathode electrolyte from $20 \mathrm{~min}$ before the reaction until the reaction was completed. During the reactions, the outlet gases were periodically analysed via gas chromatography (GC, 7820A Agilent Technologies, Inc., USA) equipped with an HP-FFAP column (30 m $\times 530 \mu \mathrm{m} \times 1.00 \mu \mathrm{m})$ and flame-ionization detector. For liquid analysis, the sample was filtered using a $0.45-\mu \mathrm{m}$ hydrophilic syringe filter (13HP045AN, Advantec MFS, Inc., USA). Then, it was injected into the inlet of the GC equipped with an HP-5 $(30 \mathrm{~m} \times 320 \mu \mathrm{m} \times 0.25 \mu \mathrm{m})$ column. The products were quantified based on the external standard curves $\left(R^{2}>0.99\right)$ of the respective compounds. Propylene oxide selectivity and $\mathrm{H}_{2} \mathrm{O}_{2}$ utilisation were calculated according to the following equations:

$$
\begin{aligned}
\text { PO selectivity }(\%) & =\frac{n_{P O}}{n_{P O}+n_{P G}} \times 100 \\
\mathrm{H}_{2} \mathrm{O}_{2} \text { utilisation }(\%) & =\frac{n_{P O}+n_{P G}}{n_{H_{2} O_{2}-n^{r} H_{2} O_{2}}} \times 100,
\end{aligned}
$$

where $n_{P O}, n_{P G}, n_{H_{2} O_{2}}$, and $n_{H_{2} O_{2}}^{r}$ indicate $\mathrm{PO}$ production, $\mathrm{PG}$ production, $\mathrm{H}_{2} \mathrm{O}_{2}$ production, and the remaining $\mathrm{H}_{2} \mathrm{O}_{2}$, respectively.

\section{Declarations}

\section{Data availability}

All experimental data are available in the main text or the supplementary information. The datasets are available from the corresponding author on reasonable request.

\section{Competing interests}

Authors declare no competing interests. 


\section{Author contributions}

J.H.K., J.-W.J., and S.H.J. proposed and directed the project. M.K., Y.K., and J.W. conceived and designed the experiments. M.K. prepared the $\mathrm{TiO}_{2}$ and $\mathrm{BiVO}_{4}$ photocatalysts and measured their performances with R.M. and P.S. Y.K. synthesised and characterised the TS-1 catalyst. J.W. prepared the Co-N/CNT electrocatalysts and measured their selectivity for $\mathrm{H}_{2} \mathrm{O}_{2}$ production. M.K. and Y.K. measured the performance of propylene oxide conversion. J.K. and H.Y.J. contributed to transmitted electron microscopy analysis. M.K., Y.K., J. W., S.H.J., J.-W.J., and J.H.K. co-wrote the manuscript. All authors read and commented on the manuscript.

\section{References}

1. Zuwei, X., Ning, Z., Yu, S. \& Kunlan, L. Reaction-controlled phase-transfer catalysis for propylene epoxidation to propylene oxide. Science 292, 1139-1141 (2001).

2. Leow, W. R. et al. Chloride-mediated selective electrosynthesis of ethylene and propylene oxides at high current density. Science 368, 1228-1233 (2020).

3. Zhan, C. et al. Critical roles of doping $\mathrm{Cl}$ on $\mathrm{Cu}_{2} \mathrm{O}$ nanocrystals for direct epoxidation of propylene by molecular oxygen. J. Am. Chem. Soc. 142, 14134-14141 (2020).

4. Teržan, J., Huš, M., Likozar, B. \& Djinović, P. Propylene epoxidation using molecular oxygen over copper- and silver-based catalysts: A review. ACS Catal. 10, 13415-13436 (2020).

5. Cavani, F. \& Teles, J. H. Sustainability in catalytic oxidation: An alternative approach or a structural evolution? ChemSusChem 2, 508-534 (2009).

6. Lei, Y. et al. Increased silver activity for direct propylene epoxidation via subnanometer size effects. Science 328, 224-228 (2010).

7. Ghosh, S. et al. Selective oxidation of propylene to propylene oxide over silver-supported tungsten oxide nanostructure with molecular oxygen. ACS Catal. 4, 2169-2174 (2014).

8. Huang, J. et al. Propene epoxidation with dioxygen catalyzed by gold clusters. Angew. Chem., Int. Ed. 48, 7862-7866 (2009).

9. Torres, D., Lopez, N., Illas, F. \& Lambert, R. M. Low-basicity oxygen atoms: A key in the search for propylene epoxidation catalysts. Angew. Chem., Int. Ed. 46, 2055-2058 (2007).

10. Barton, J. L. Electrification of the chemical industry. Science 368, 1181-1182 (2020).

11. Gordon, C. P. et al. Efficient epoxidation over dinuclear sites in titanium silicalite-1. Nature 586, 708713 (2020).

12. Campos-Martin, J. M., Blanco-Brieva, G. \& Fierro, J. L. G. Hydrogen peroxide synthesis: an outlook beyond the anthraquinone process. Angew. Chem., Int. Ed. 45, 6962-6984 (2006).

13. Hayashi, T., Tanaka, K. \& Haruta, M. Selective vapor-phase epoxidation of propylene over $\mathrm{Au} / \mathrm{TiO}_{2}$ catalysts in the presence of oxygen and hydrogen. J. Catal. 178, 566-575 (1998). 
14. Uphade, B. S., Akita, T., Nakamura, T. \& Haruta, M. Vapor-phase epoxidation of propene using $\mathrm{H}_{2}$ and $\mathrm{O}_{2}$ over Au/Ti-MCM-48. J. Catal. 209, 331-340 (2002).

15. Sinha, A. K., Seelan, S., Tsubota, S. \& Haruta, M. A three-dimensional mesoporous titanosilicate support for gold nanoparticles: Vapor-phase epoxidation of propene with high conversion. Angew. Chem., Int. Ed. 43, 1546-1548 (2004).

16. Liu, B. \& Aydil, E. S. Growth of oriented single-crystalline rutile $\mathrm{TiO}_{2}$ nanorods on transparent conducting substrates for dye-sensitized solar cells. J. Am. Chem. Soc. 131, 3985-3990 (2009).

17. Liu, C., Tang, J., Chen, H. M., Liu, B. \& Yang, P. A fully integrated nanosystem of semiconductor nanowires for direct solar water splitting. Nano Lett. 13, 2989-2992 (2013).

18. Wang, G. et al. Hydrogen-treated $\mathrm{TiO}_{2}$ nanowire arrays for photoelectrochemical water splitting. Nano Lett. 11, 3026-3033 (2011).

19. Blasco, T., Camblor, M. A., Corma, A. \& Perez-Pariente, J. The state of Ti in titanoaluminosilicates isomorphous with zeolite .beta. J. Am. Chem. Soc. 115, 11806-11813 (1993).

20. Fan, W. et al. Synthesis, crystallization mechanism, and catalytic properties of titanium-rich TS-1 free of extraframework titanium species. J. Am. Chem. Soc. 130, 10150-10164 (2008).

21. Möller, S. et al. Online monitoring of electrochemical carbon corrosion in alkaline electrolytes by differential electrochemical mass spectrometry. Angew. Chem., Int. Ed. 59, 1585-1589 (2020).

22. Bader, H., Sturzenegger, V. \& Hoigné, J. Photometric method for the determination of low concentrations of hydrogen peroxide by the peroxidase catalyzed oxidation of N,N-diethyl-pphenylenediamine (DPD). Water Res. 22, 1109-1115 (1988).

23. Ko, M. et al. Unassisted solar lignin valorisation using a compartmented photo-electro-biochemical cell. Nat. Commun. 10, 5123 (2019).

24. Li, B. et al. Hydration of epoxides on [Co'l'(salen)] encapsulated in silica-based nanoreactors. Angew. Chem., Int. Ed. 51, 11517-11521 (2012).

25. Khouw, C. B. \& Davis, M. E. Catalytic activity of titanium silicates synthesized in the presence of alkali-metal and alkaline-earth ions. J. Catal. 151, 77-86 (1995).

26. Park, Y., McDonald, K. J. \& Choi, K.-S. Progress in bismuth vanadate photoanodes for use in solar water oxidation. Chem. Soc. Rev. 42, 2321-2337 (2013).

27. Kim, T. W. \& Choi, K.-S. Nanoporous $\mathrm{BiVO}_{4}$ photoanodes with dual-layer oxygen evolution catalysts for solar water splitting. Science 343, 990-994 (2014).

28. Zhong, D. K., Choi, S. \& Gamelin, D. R. Near-complete suppression of surface recombination in solar photoelectrolysis by "Co-Pi" catalyst-modified W:BiVO 4 . J. Am. Chem. Soc. 133, 18370-18377 (2011).

29. Lee, Y. W. et al. Unbiased biocatalytic solar-to-chemical conversion by $\mathrm{FeOOH} / \mathrm{BiVO}_{4} /$ perovskite tandem structure. Nat. Commun. 9, 4208 (2018).

30. Lee, D. K. \& Choi, K.-S. Enhancing long-term photostability of $\mathrm{BiVO}_{4}$ photoanodes for solar water splitting by tuning electrolyte composition. Nat. Energy 3, 53-60 (2018). 
31. Tan, H. L. et al. Interfacing $\mathrm{BiVO}_{4}$ with reduced graphene oxide for enhanced photoactivity: A tale of facet dependence of electron shuttling. Small 12, 5295-5302 (2016).

32. Liu, X., Richtering, W. \& Akolkar, R. Investigation of the kinetics and mass transport aspects of hydrogen evolution during electroless deposition of nickel-phosphorus. J. Electrochem. Soc. 164, D498-D504 (2017).

33. Chenlo, F., Moreira, R., Pereira, G. \& Vázquez, M. J. Viscosity of binary and ternary aqueous systems of $\mathrm{NaH}_{2} \mathrm{PO}_{4}, \mathrm{Na}_{2} \mathrm{HPO}_{4}, \mathrm{Na}_{3} \mathrm{PO}_{4}, \mathrm{KH}_{2} \mathrm{PO}_{4}, \mathrm{~K}_{2} \mathrm{HPO}_{4}$, and $\mathrm{K}_{3} \mathrm{PO}_{4}$. J. Chem. Eng. Data 41, 906-909 (1996).

34. Yin, G. \& Zhang, J. Rotating electrode methods and oxygen reduction electrocatalysts. (Elsevier, 2014).

35. Khomane, R. B., Kulkarni, B. D., Paraskar, A. \& Sainkar, S. R. Synthesis, characterization and catalytic performance of titanium silicalite-1 prepared in micellar media. Mater. Chem. Phys. 76, 99-103 (2002).

\section{Figures}

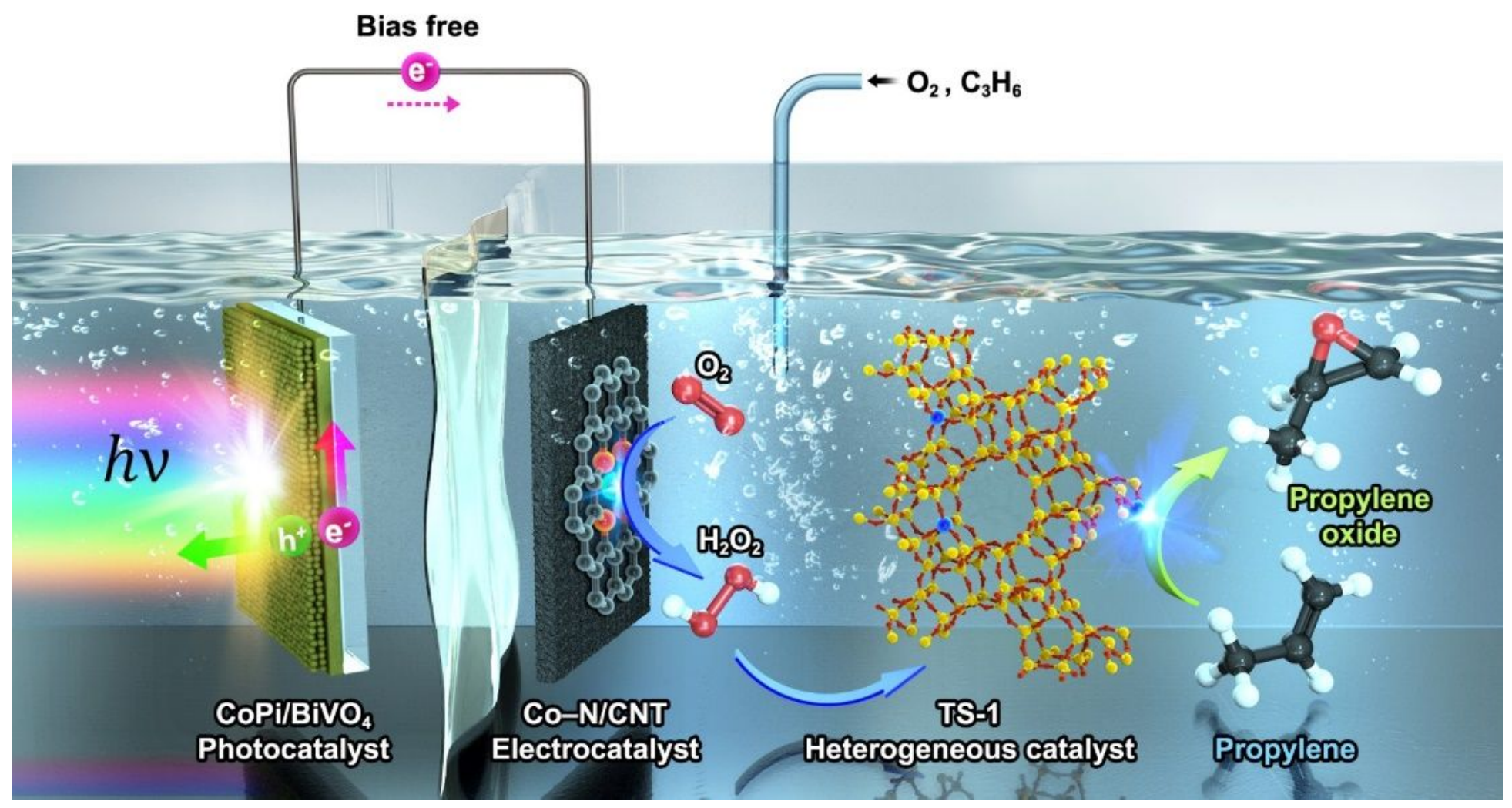

Figure 1

Schematic of bias-free PO production in photo-electro-heterogeneous catalytic system. The CoPi/BiVO4 (cobalt phosphate loaded bismuth vanadate) photocatalyst promotes water oxidation under light 
illumination and then the $\mathrm{Co}-\mathrm{N} / \mathrm{CNT}$ electrocatalyst carries out continuous $\mathrm{O} 2$ reduction to $\mathrm{H} 2 \mathrm{O} 2$. A Nafion proton exchange membrane separates the anodic and cathodic parts of the photo-electrochemical cell. Along with in situ generated H2O2, TS- 1 heterogeneous catalyst continuously epoxidises propylene to $\mathrm{PO}$ by consuming $\mathrm{H} 2 \mathrm{O} 2$ as an oxidising agent.

a

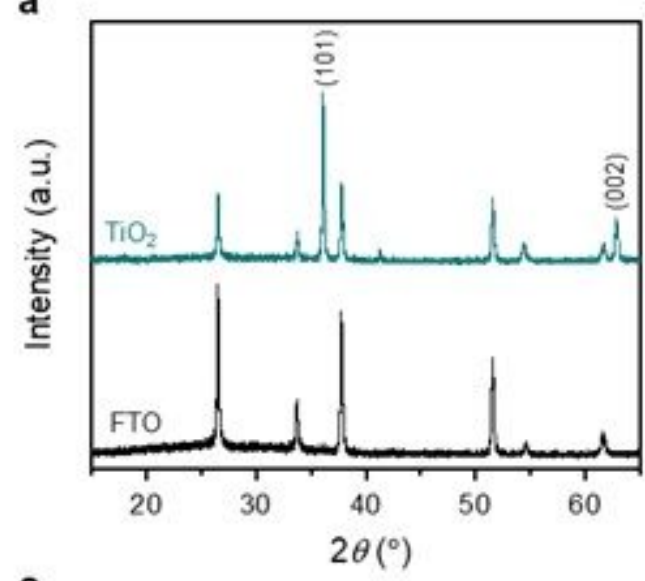

C

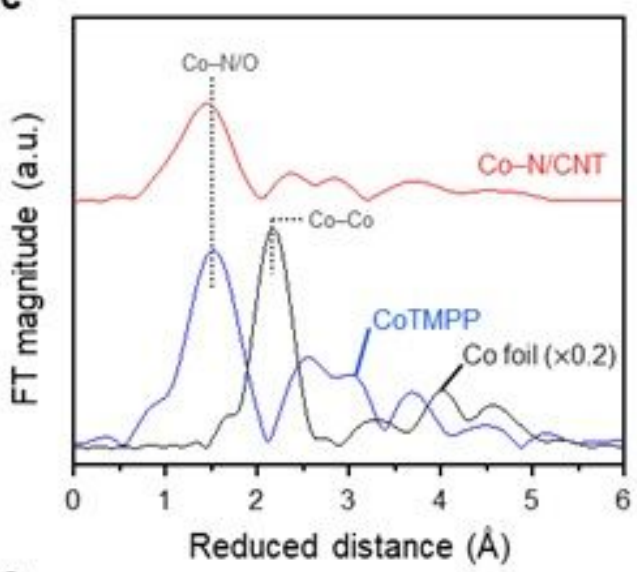

e

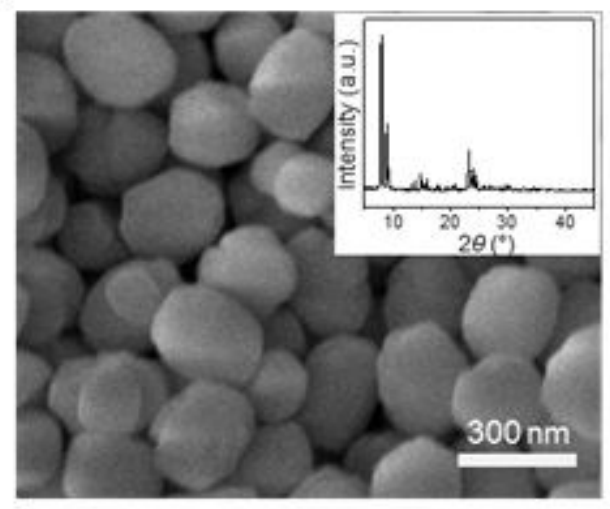

b

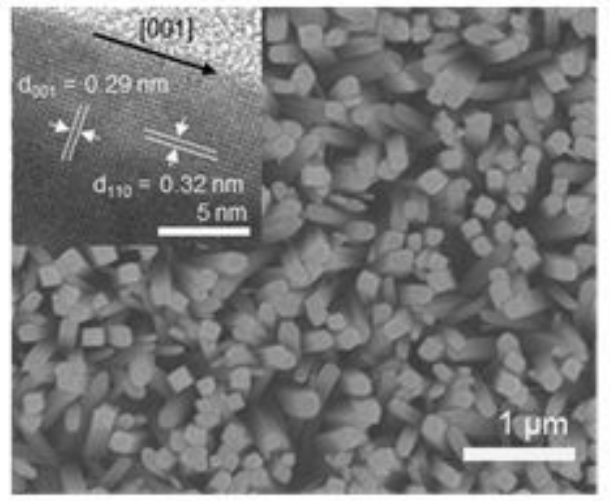

d

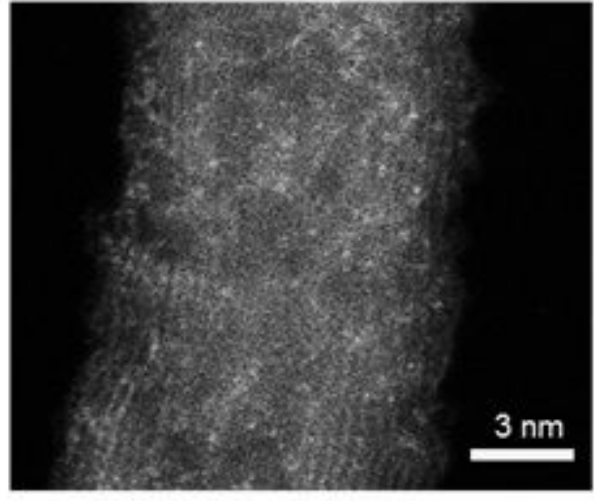

f

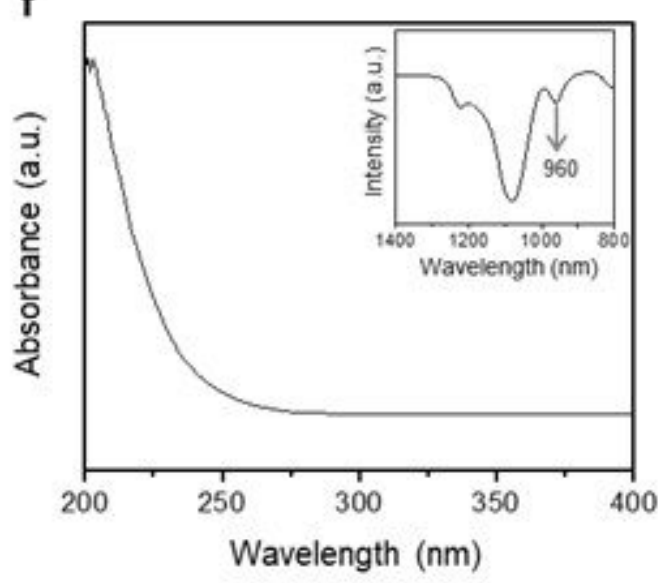

Figure 2

Catalyst characterisation. a, XRD patterns of TiO2/FTO and FTO. b, SEM and HRTEM (inset) images of TiO2 photoanode. c, EXAFS spectra of Co-N/CNT, CoTMPP, and Co foil. d, HAADF-STEM images of CoN/CNT. e, SEM image and XRD pattern (inset) of TS-1. $f$, UV-Vis diffuse reflectance spectra and FT-IR spectra (inset) of TS-1. 
a

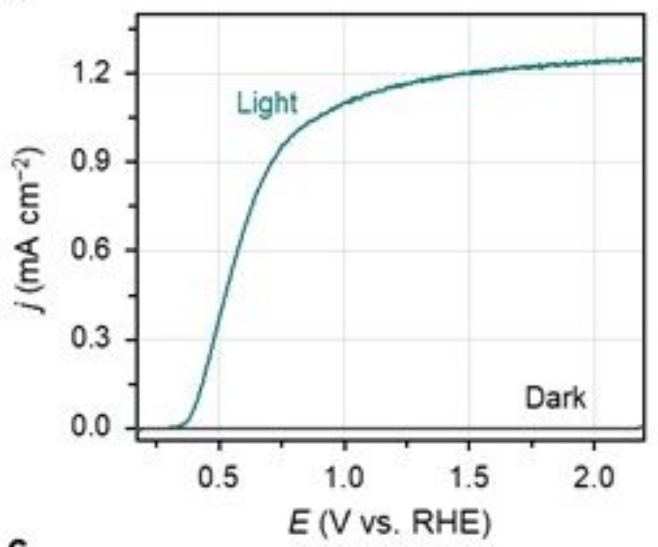

C

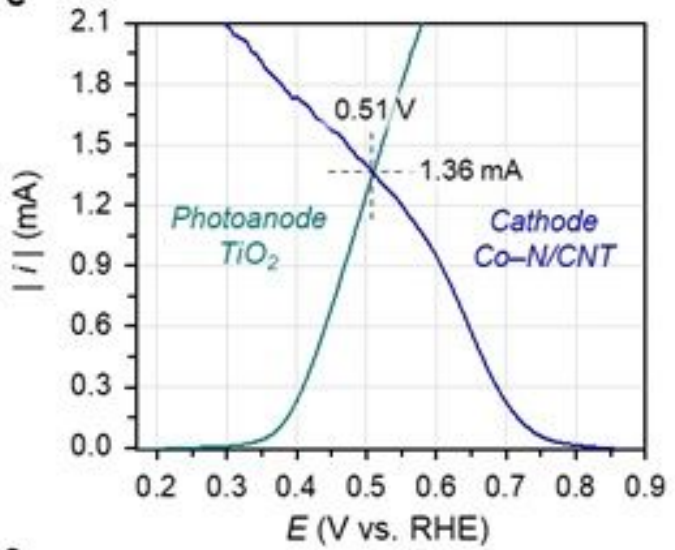

e

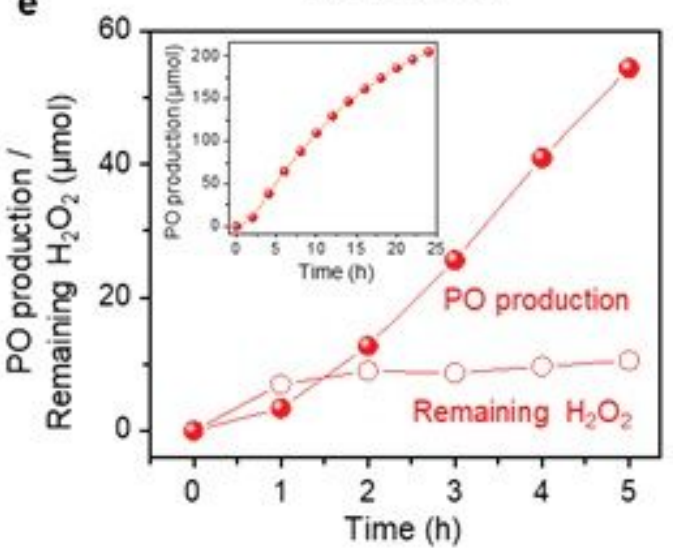

b
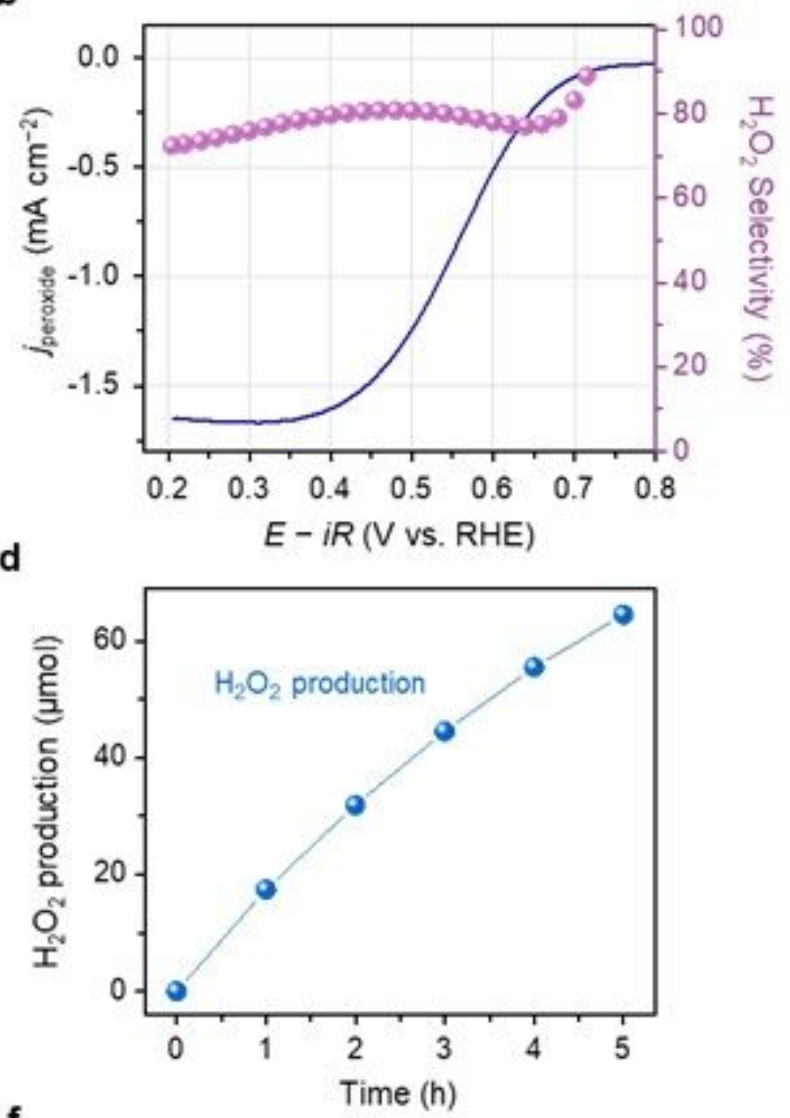

f

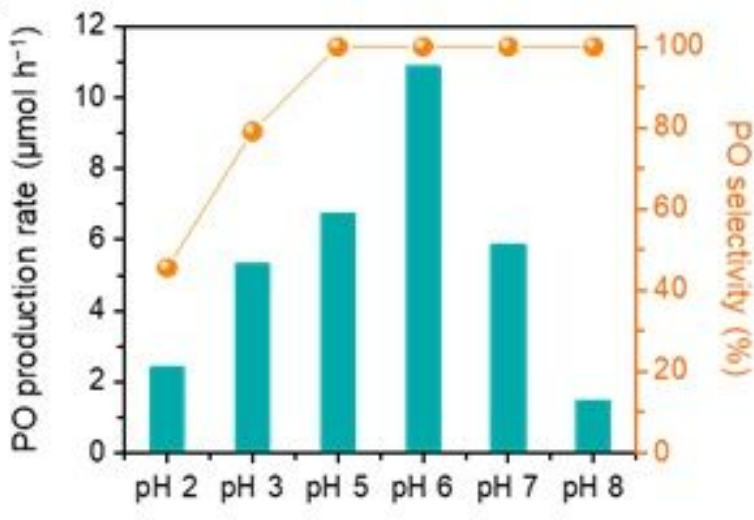

Figure 3

Bias-free photo-electrochemical $\mathrm{H} 2 \mathrm{O} 2$ production and propylene epoxidation in photo-electroheterogeneous catalytic system. a, Photocurrent density of TiO2 photoanode under simulated solar light irradiation and dark conditions in an Ar-saturated 0.1 M NaPi buffer at pH 6. b, LSV curves and H2O2 selectivity of Co-N/CNT catalyst in an 02-saturated $0.1 \mathrm{M} \mathrm{NaPi}$ buffer at pH 6. c, Overlap of LSV curves of TiO2 photoanode and Co-N/CNT on carbon paper in Ar- and 02-saturated 0.1 M NaPi buffers at pH 6 . d, $\mathrm{H} 2 \mathrm{O} 2$ production during the photo-electrochemical (TiO2 photoanode and $\mathrm{Co}-\mathrm{N} / \mathrm{CNT}$ cathode) reaction in a $0.1 \mathrm{M} \mathrm{NaPi}$ buffer at $\mathrm{pH}$ 6. e, $\mathrm{PO}$ production and remaining $\mathrm{H} 2 \mathrm{O} 2$ during the reactions in photo-electro-heterogeneous catalytic system in a $0.1 \mathrm{M} \mathrm{NaPi}$ buffer at $\mathrm{pH}$ 6. Inset: $\mathrm{PO}$ production for 24 
h. $\mathrm{f}, \mathrm{PO}$ production rate and $\mathrm{PO}$ selectivity after $5 \mathrm{~h}$ of reaction in different $\mathrm{pH}$ solutions. All light was simulated as one sun (air mass 1.5 global, AM 1.5 G) of illumination.

a

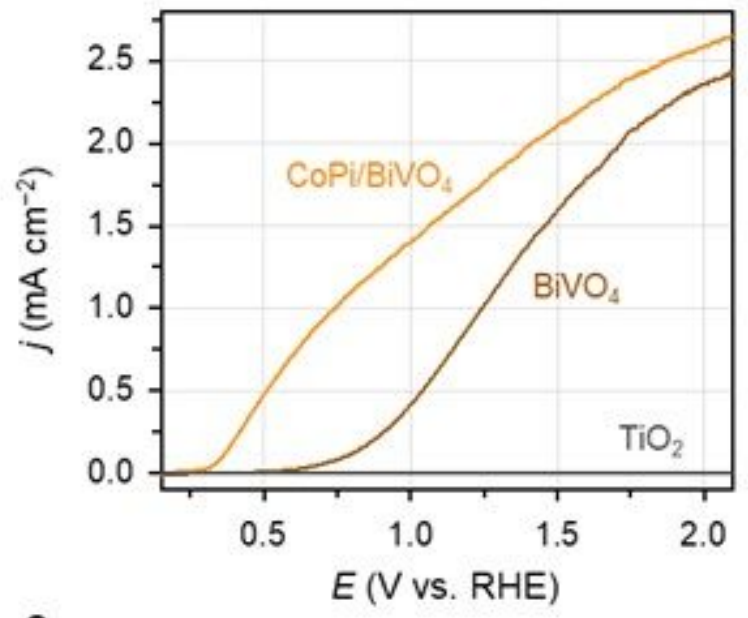

C

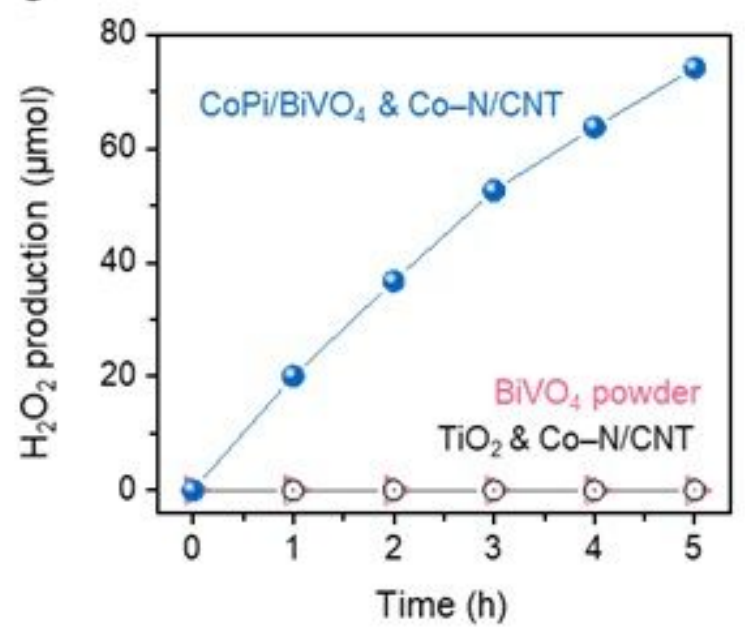

b

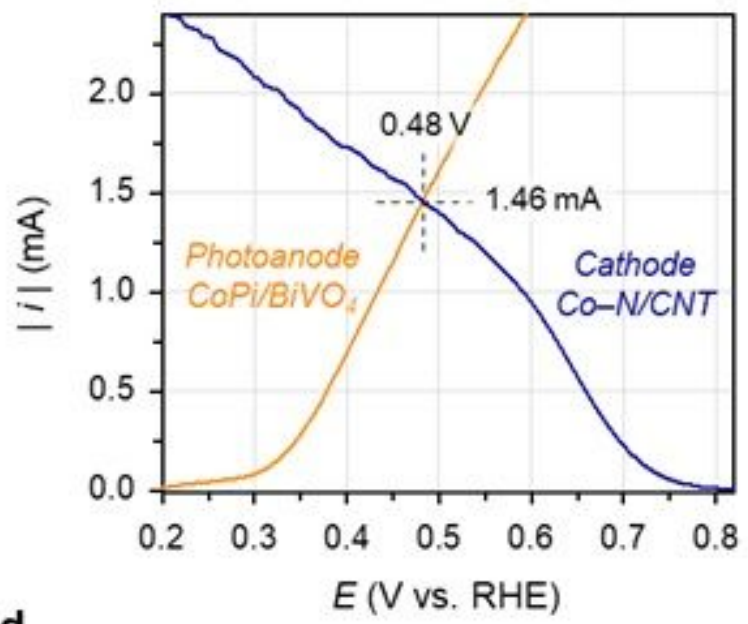

d

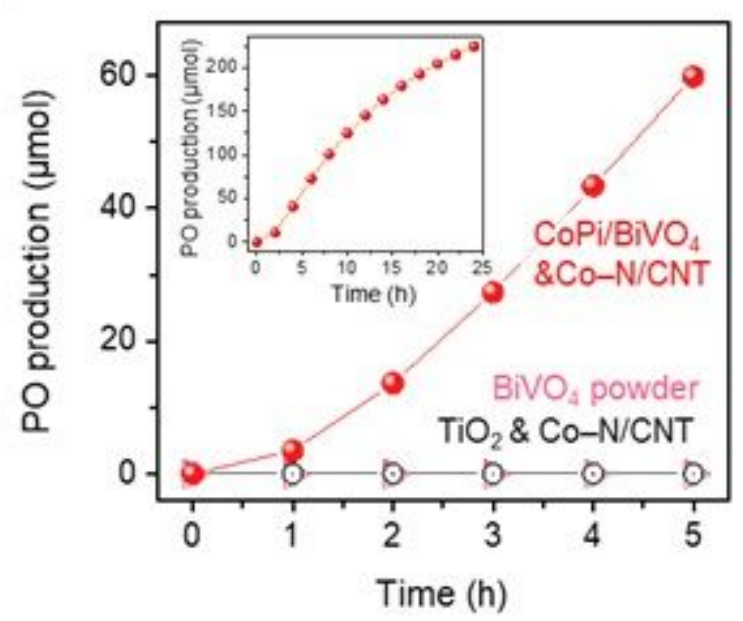

\section{Figure 4}

Bias-free photo-electrochemical $\mathrm{H} 2 \mathrm{O} 2$ production and further integration with TS-1 for PO production under visible light. a, Photocurrent density of $\mathrm{CoPi} / \mathrm{BiVO4}$, BiVO4, and TiO2 photoanodes in an Arsaturated $0.1 \mathrm{M} \mathrm{NaPi}$ buffers at $\mathrm{pH} 6$ under visible light $(\lambda>420 \mathrm{~nm})$ illumination. b, Overlap of the LSV curves of CoPi/BiVO4 photoanode and Co-N/CNT on carbon paper in Ar- and 02-saturated, 0.1 M NaPi buffers at $\mathrm{pH} 6$, respectively. $\mathrm{C}, \mathrm{H} 2 \mathrm{O} 2$ production during the photo-electrochemical and BiVO4 photocatalytic reaction in a $0.1 \mathrm{M} \mathrm{NaPi}$ buffer at $\mathrm{pH}$ 6. $\mathrm{d}, \mathrm{PO}$ production in photo-electro-heterogeneous catalytic and photo-heterogeneous catalytic (BiVO4 powder) system in a $0.1 \mathrm{M} \mathrm{NaPi}$ buffer at pH 6. The light intensity was $160 \mathrm{~mW} \mathrm{~cm}-2$, with a $420 \mathrm{~nm}$ cutoff filter.

\section{Supplementary Files}

This is a list of supplementary files associated with this preprint. Click to download.

- SINatCat.pdf 